DOI: https://doi.org/10.32839/2304-5809/2021-4-92-22

удК 347.5

Никончук Н.С., Коробцова Н.В.

Національний юридичний університет імені Ярослава Мудрого

\title{
ВІДШКОДУВАННЯ МОРАЛЬНОЇ ШКОДИ У ДОГОВІРНИХ ЗОБОВ'ЯЗАННЯХ: АНАЛІЗ ПРАВОЗАСТОСОВНОЇ ПРАКТИКИ
}

\begin{abstract}
Анотація. У даній статті висвітлено питання щодо застосування інституту моральної шкоди у договірних зобов'язаннях як одного із основних способів цивільно-правового захисту з огляду на правозастосувальну практику національних судів протягом останніх років. Проаналізовано зміст права на відшкодування моральної шкоди в цілому та висвітлено зміни в правових позиціях Верховного суду щодо компенсації моральної шкоди на підставі статті 23 Цивільного кодексу України. Відповідно до проведеного аналізу правозастосовної практики, положень статей 16 і 23 ЦК України та змісту права на відшкодування моральної шкоди в цілому як способу захисту суб'ективного цивільного права зроблено висновок про те, що компенсація моральної шкоди повинна відбуватися у будь-якому випадку її спричинення - право на відшкодування моральної (немайнової) шкоди виникає внаслідок порушення права особи незалежно від наявності спеціальних норм цивільного законодавства задля забезпечення принципу правової визначеності як одного із фундаментальних аспектів верховенства права.
\end{abstract}

Ключові слова: моральна шкода, відшкодування, договірні зобов’язання, правозастосування, Верховний Суд, Свропейський суд з прав людини.

Nykonchuk Natalia, Korobtsova Natalia Yaroslav Mudryi National Law University

\section{INDEMNIFICATION OF THE MORAL DAMAGE IN CONTRACTUAL OBLIGATIONS: PRACTICAL ASPECTS}

Summary. In the article are analyzed the characteristics of indemnity of moral (non-property) damage in contractual obligations as a way to protect the civil rights and interests, that in its legal nature relates to measures of civil liability. Exploring this topic, the authors analyze national and foreign legislation, theoretical approaches and the practice of the European Court of Human Rights. The most important task of modern legal science and practice - the creation of legal mechanisms, allowing most effectively to ensure the proper performance of contractual obligations and to compensate the injured party for the moral damage by their failure or improper performance. In addition, on the basis of research into the development of the Institute for the Compensation of Moral Harm in Ukraine, special attention is paid to determining the main factors reflecting the current state of the institute. In the article is emphasized the crucial role of the principles of fairness, reasonableness and good faith in the legal regulation of relations with the indemnity of non-pecuniary damage. In addition, on the basis of generalization of legislative provisions and judicial practice, the main thesis of these documents on the compensation of non-pecuniary damage is reduced to the fact that, first, the right to compensation for moral damage must be provided for by law or agreement, and the court shall establish what the fact of causing the plaintiff to cause loss of non-property character, in what circumstances or by what actions they are caused, in what amount or in what material form the plaintiff assesses the harm he caused and on what grounds end so estimates and other circumstances relevant to the dispute. According to the analysis of recent law enforcement practice, Articles 16 and 23 of the Civil Code of Ukraine and the content of the right to compensation for moral damage in general as a way to protect subjective civil rights, the conclusion is that compensation for moral damage should occur in any case of its infliction - the right to compensation for moral (non-property) damage arises from the violation of human rights regardless of special rules of civil law to ensure the principle of legal certainty as one of the fundamental aspects of the rule of law.

Keywords: moral damage, indemnification, contractual obligations, judicial practice, Supreme Court, European Court of Human Rights.

$\Pi^{2}$ остановка проблеми. Відшкодування моральної шкоди є одним із основних способів цивільно-правового захисту не лише немайнових, а й майнових суб'єктивних цивільних прав. Метою застосування інституту відшкодування моральної шкоди насамперед $є$ компенсація виключно немайнових втрат потерпілого (ст. 23, 1167 Цивільного кодексу України).

Аналіз різних за змістом судових рішень дає підстави для дослідження й з'ясування можливості та особливостей відшкодування моральної шкоди у сорері договірних відносин, адже нині позови про відшкодування моральної шкоди набувають все більшої популярності, у т.ч. і у зв'язку з відсутністю законодавчого врегулювання мінімального та максимального розмірів такого відшкодування.
Аналіз останніх досліджень i публікацій. У зв'язку з існуванням низки практичних та теоретичних проблем застосування інституту відшкодування моральної шкоди, багато видатних цивілістів приділили значну увагу для дослідження питань, пов'язаних з відшкодуванням моральної шкоди у договірних зобов'язаннях. До таких вчених, зокрема, належать: О. В. Грищук, А. Б. Гриняк, Н. Міловська, К. Б. Дудорова, П. М. Рабінович, С. І. Шимон та ін.

Метою статті $€$ дослідження особливостей розвитку інституту відшкодування моральної шкоди в Україні, а також його застосування в договірних зобов'язаннях 3 огляду на зміни в правозастосовній практиці протягом останніх років. 
Виклад основного матеріалу. Частинами 1 , 4, 5 ст. 23 ЦК України встановлено, що особа має право на відшкодування моральної шкоди, завданої внаслідок порушення іï прав; моральна шкода відшкодовуеться незалежно від майнової шкоди, яка підлягає відшкодуванню, та не пов'язана з розміром цього відшкодування; моральна шкода відшкодовуеться одноразово, якщо інше не встановлено договором або законом [1].

У чинному законодавстві України відсутне легальне визначення поняття моральної шкоди, проте відповідно до п. 3 Постанови Пленуму Верховного Суду України «Про судову практику в справах про відшкодування моральної (немайнової) шкоди» від 31.03.1995 року під моральною шкодою потрібно розуміти втрати немайнового характеру внаслідок моральних чи фбізичних страждань, або інших негативних явищ, заподіяних фбізичній чи юридичній особі незаконними діяли або бездіяльністю інших осіб [2].

У вітчизняній цивілістищі щодо тлумачення поняття моральної шкоди існуе дві основні тенденщії: одні вчені вважають, що моральна шкода - це фізичні й моральні страждання особи, права якої порушено, інші - що це не самі страждання, а зумовлені ними втрати немайнового характеру [3, с. 36].

Відповідно до ст. 611 ЦК України, можна стверджувати, що відшкодування моральної (немайнової) шкоди в договірних правовідносинах може здійснюватися виключно у випадках, що прямо передбачені законом або укладеним договором.

Європейський суд з прав людини у своєму рішенні у справі «Новоселецький проти України» від 22 лютого 2005 року (п.п. 22, 76) висловив «особливе здивування» щодо відхилення нащіональним судом позову про відшкодування моральної шкоди 3 посиланням на те, що «відшкодування моральної шкоди у житлово-правових спорах законом не передбачено» [4], що визначае умови застосування ст. ст. 23, 1167 ЦК України та підтверджуе визнання інституту відшкодування моральної шкоди як загального способу захисту, незалежно від передбачуваності цього права в спеціальних законах.

Згідно з ч. 3 ст. 23 ЦК України, розмір грошового відшкодування моральної шкоди визначаеться судом залежно від характеру правопорушення, глибини фрізичних i душевних страждань, погіршення здібностей потерпілого або позбавлення його можливості їх реалізації, ступеня вини особи, яка завдала моральної шкоди, якщо вина є підставою для відшкодування, часу, що минув із моменту виникнення моральної шкоди, а також з урахуванням інших обставин, які мають істотне значення [1].

Європейський суд з прав людини вказуе, що оцінка моральної шкоди по своему характеру є складним процесом, за винятком випадків коли сума компенсації встановлена законом (Stankov v. Bulgaria, № 68490/01, § 62, ССПЛ, 12 липня 2007 року) [5]. Саме тому розмір відшкодування моральної шкоди має умовний характер, оскільки немае точних критеріїв майнового вираження душевного болю, спокою, честі, гідності особи, але у будь-якому випадку розмір відшкодування моральної шкоди повинен бути достатнім для задоволення потреб потерпілого й не повинен призводити до його збагачення.
Відшкодування моральної (немайнової) шкоди, за загальним правилом, здійснюеться у формі одноразової виплати грошової суми в повному обсязі або передачі іншого майнового блага. Спосіб відшкодування може встановлюватися законом. За погодженням між сторонами або за рішенням суду моральна шкода може бути відшкодована й шляхом наданні благ іншого майнового характеру: безкоштовних путівок до лікувально-оздоровчих закладів (санаторії, будинки відпочинку), у туристичну подорож, виконання послуг або робіт (ремонт житлового приміщення, перевезення, опублікування твору, автором якого є потерпілий, косметичні, медичні послуги тощо) [3, с. 37].

Порушення договору як підстава для виникнення права на відшкодування моральної шкоди може виявлятися як у невиконанні, так і в неналежному виконанні договірних зобов'язань. Наприклад, у разі розголошення банком відомостей, що становлять банківську таємницю, кліент мае право вимагати від банку відшкодування завданих збитків та моральної шкоди (ч. 2 ст. 1076 ЦК України).

Відповідно до Постанови Верховного Суду у складі колегії суддів Другої судової палати Касаційного цивільного суду від 25 листопада 2019 року у справі № 214/9480/14 (провадження № 61-30656св18) відбулося стягнення компенсації моральної шкоди за договором купівлі-продажу, адже відповідно до частини другої статті 22 Закону України «Про захист прав споживачів» при задоволенні вимог споживача суд одночасно вирішуе питання щодо відшкодування моральної (немайнової) шкоди. У даному випадку суди встановили, що після демонстрації косметичних засобів 29 серпня 2014 року позивач та TOB «Краса плюс» уклали договір купівлі-продажу № 241 комплекту косметичної продукції під товарним знаком «Дешелі», але після використання косметики у позивача виникла алергічна реакщія на шкірі, 12 вересня 2014 року після огляду дерматолога клініки «Медиком» їй установлено діагноз «алергічна кропивниця на вечірній та денний крем для обличчя, гель для очей, маску для обличчя фірми «Дешелі», тому суд дійшов обгрунтованого висновку про наявність підстав для стягнення з відповідача на користь позивача відшкодування моральної шкоди у розмірі, що відповідає засадам розумності та справедливості, а також обставинам справи та наслідкам, що наступили для позивача, яка зазнала моральних страждань та втрат немайнового характеру $[6$, с. 6].

Або ж, наприклад, Верховним Судом (Постанова Верховного Суду у складі колегії суддів Першої судової палати Касаційного цивільного суду від 05 лютого 2020 року у справі № 243/9071/18 (провадження № 61-13650св19) було стягнуто моральну шкоду за договором повітряного перевезення, дійшовши висновку, що TOB «Авіакомпанія Скайап» було скасовано рейс KUP 5410 від 17 червня 2018 року, чим завдано душевні страждання позивачам, оскільки останні не здійснили виліт у запланований час та вимушені були чекати іншого рейсу тривалий час, суд першої інстанції обгрунтовано стягнув на користь позивачів моральну шкоду у розміpi 2000 грн кожному, при цьому, врахувавши 
принципи законності, об'єктивності, розумності та справедливості [6, с. 18].

Проте постає проблема застосування інституту відшкодування моральної шкоди за порушення цивільно-правового договору, якщо умовами договору право на компенсацію моральної шкоди не передбачено та відсутні такі вказівки у нормах ЦК України чи інших законів, що регулюють відповідний вид договору. Так, Європейський суд 3 прав людини у $\S 45$ по справі VOLOVIK v. UKRAINE від 06 грудня 2007 року № 15123/03, зауважує, що національні суди мають вибирати способи такого тлумачення, які зазвичай можуть включати акти законодавства, відповідну практику, наукові дослідження тощо [7].

Раніше у судовій практищі Верховного Суду України та Великої палати Верховного Суду було сфрормовано підхід про те, що моральна шкода за порушення договору не може бути компенсована, якщо це прямо не передбачено законом або тим чи іншим договором. Зокрема у постанові Верховного Суду України від 06 червня 2012 року у справі № 6-49цс12 зроблено висновок, що «разом з тим суди дійшли обгрунтованого висновку про відмову в задоволенні позову в частині моральної шкоди, оскільки ні договором страхування, ні законом таке відшкодування не передбачено. Зазначений висновок грунтується на вимогах статті 611 ЦК України, відповідно до якої відшкодування моральної шкоди в разі невиконання зобов'язання допускається, якщо такі наслідки передбачені законом або договором».

Проте очевидним є той фракт, що різний підхід до стягнення збитків та компенсащії моральної шкоди і відповідно різні умови для застосування статей ЦК України (зокрема, 22 і 23), не може розглядатися в контексті динамічного розвитку судової практики і забезпечити розумну передбачуваність судових рішень, адже неоднакове тлумачення законодавства може призвести до проблем у правозастосовній практиці.

Таким чином, колегія суддів у Постанові від 01 вересня 2020 року у справі № 216/3521/16-ц (провадження № 14-714цс19) [8] вказала, що компенсація моральної шкоди за порушення цивільно-правового договору може бути стягнута на підставі статті 23 ЦК України навіть у тих випадках, коли умовами договору право на компенсацію моральної шкоди не передбачено та не містять таких вказівок норми ЦК України чи іншого закону, що регулюють відповідний вид договору, саме тому у зв'язку з цим, колегія суддів відступила від висновку щодо застосування норми права у подібних правовідносинах, викладених в раніше ухвалених рішеннях Верховного Суду України (постанова Верховного Суду України від 06 червня 2012 року у справі № 6-49цс12, постанова Верховного Суду України від 24 лютого 2016 року у справі № 6-1790цс15) та Великої Палати Верховного Суду (постанова Великої Палати Верховного Суду 20 березня 2019 року у справі № 761/26293/16-ц (провадження № 14-64цс19) [6, с. 26].

Висновки. Аналіз правозастосовної практики, положень статей 16 і 23 ЦК України та змісту права на відшкодування моральної шкоди в цілому як способу захисту суб єктивного цивільного права свідчить про те, компенсація моральної шкоди повинна відбуватися у будь-якому випадку її спричинення - право на відшкодування моральної (немайнової) шкоди виникає внаслідок порушення права особи незалежно від наявності спеціальних норм цивільного законодавства - задля забезпечення принщипу правової визначеності як одного із фрундаментальних аспектів верховенства права.

\section{Список літератури:}

1. Цивільний кодекс України від 16.01.2003 p. № 435-IV. URL: https://zakon.rada.gov.ua/laws/show/435-15\#Text (дата звернення: 10.04.2021).

2. Про судову практику в справах про відшкодування моральної (немайнової) шкоди : Постанова Пленуму Верховного Суду України від 31 березня 1995 року № 4 в редакції від 27 лютого 2009 р. URL: https://zakon.rada.gov.ua/laws/show/v0004700-95\#Text (дата звернення: 11.04.2021).

3. Міловська Н. Особливості відшкодування моральної (немайнової) шкоди в зобов'язаннях зі страхування. Підприемництво, господарство і право. Цивільне право і процес. 2017. Вип. 3. С. 35-39. URL: http://pgp-journal.kiev.ua/archive/2017/3/9.pdf (дата звернення: 13.04.2021).

4. «Новоселецький проти України» : Рішення Свропейського суду з прав людини від 22 лютого 2005 р. // База даних «Законодавство України». URL: https://zakon.rada.gov.ua/laws/show/980_238\#Tехt (дата звернення: 11.04.2021).

5. «Stankov v. Bulgaria» : Рішення Європейського суду з прав людини № 25820/07 від 12 липня 2007 року. URL: http://docs.pravo.ru/document/view/19383193/ (дата звернення: 15.04.2021).

6. Практика Верховного Суду у справах про компенсацію моральної шкоди від 18 грудня 2020 р. Ст. 44. URL: https://supreme.court.gov.ua/userfiles/media/new_folder_for_uploads/supreme/Krat_V_18_12_2020.pdf (дата звернення: 13.04.2021).

7. «Volovik v. Ukraine» : Рішення Свропейського суду з прав людини № 15123/03 від 06 грудня 2007 р. // База даних «Законодавство України». URL: https://zakon.rada.gov.ua/laws/show/974_336\#Tехt (дата звернення: 15.04.2021).

8. Постанова Великої Палати Верховного Суду від 01 вересня 2020 року у справі № 216/3521/16-ц (провадження № 14-714цс19). URL: https://verdictum.ligazakon.net/document/91644731 (дата звернення: 11.04.2021).

\section{References:}

1. The Civil Code of Ukraine № 435-IV (2003, January 16). Available at: https://zakon.rada.gov.ua/laws/show/ 435-15\#Text (accessed 10 April 2021).

2. About judicial practice in cases of non-pecuniary (non-property) damage Decision of the Supreme Court of Ukraine on March 3, 1995. Available at: https://zakon.rada.gov.ua/laws/show/v0004700-95\#Text (accessed 11 April 2021).

3. Milovska N. (2017) Osoblyvosti vidshkoduvannia moralnoi (nemainovoi) shkody v zobov'iazanniakh zi strakhuvannia [The characteristics of indemnity of moral (non-property) damage in insurance liabilities]. Entrepreneurship, economy and law. Civil law and process, no. 3, pp. 35-39. Available at: http://pgp-journal.kiev.ual archive/2017/3/9.pdf (accessed 13 April 2021). 
4. «Novoseletskyi v. Ukrainy»: rishennia Yevropeiskoho sudu z prav liudyny vid 22 liutoho 2005 r. (2005) [ECHR decision in the case «Novoseletsky v. Ukraine» (application no. 47148/99)]. Available at: https://zakon.rada.gov.ua/ laws/show/980_238\#Text (accessed 11 April 2021).

5. «Stankov v. Bulgaria»: rishennia Yevropeiskoho sudu z prav liudyny № 68490/01 vid 12 lypnia 2007 r. (2007) [ECHR decision in the case "Stankov v. Bulgaria» of 12 July 2007 (application no. 68490/01)]. Available at: http://docs.pravo.ru/document/view/19383193/ (accessed 15 April 2021).

6. About the practice of the Supreme Court in cases of compensation for moral damage on December $18,2020$. Available at: https://supreme.court.gov.ua/userfiles/media/new_folder_for_uploads/supreme/Krat_V_18_12_2020.pdf (accessed 13 April 2021).

7. "Volovik v. Ukraine»: rishennia Yevropeiskoho sudu z prav liudyny № 15123/03 vid 06 hrudnia 2007 r. (2007) [ECHR «Volovik v. Ukraine» (application no. 15123/03)]. Available at: https://zakon.rada.gov.ua/laws/show/974_336\#Text (accessed 15 April 2021).

8. Postanova Velykoi Palaty Verkhovnoho Sudu vid 01 veresnia 2020 roku u spravi № 216/3521/16-ts (provadzhennia № 14-714tss19) (2020). Available at: https://verdictum.ligazakon.net/document/91644731 (accessed 11 April 2021). 